\title{
Electrochemical Studies on the Corrosion of Electrically Conductive Sulfide Minerals in High Pressure Hydrothermal Fluids - a Case Study From Pyrite
}

\author{
Sen Lin, Heping $\mathrm{Li}^{*}$, Can Cui \\ Key Laboratory for High Temperature \& High Pressure Study of the Earth's Interior, Institute of \\ Geochemistry, Chinese Academy of Sciences, Guiyang, 550081, China \\ *E-mail: liheping@vip.gyig.ac.cn
}

doi: $10.20964 / 2017.01 .11$

Received: 13 September 2016 / Accepted: 19 October 2016 / Published: 12 December 2016

\begin{abstract}
Electrochemical data concerning electrically conductive sulfide minerals submitted to high pressure hydrothermal fluids above $150{ }^{\circ} \mathrm{C}$ has not been reported in spite of its significance. In this work, electrochemical impedance spectroscopy (EIS) and Tafel studies of pyrite corrosion in pure water, $3.5 \% \mathrm{NaCl}$ solution and $0.1 \mathrm{M}$ sulfuric acid with $1796 \mathrm{kPa} \mathrm{O}_{2}$ at $350{ }^{\circ} \mathrm{C}, 30 \mathrm{MPa}$ were conducted, with the assistance of a self-designed three-electrode electrochemical measurement set-up that can operate in high pressure hydrothermal fluids. Results show that in pure water, $3.5 \% \mathrm{NaCl}$ solution, and $0.1 \mathrm{M}$ sulfuric acid with $1796 \mathrm{kPa} \mathrm{O}$, corrosion potential $\left(E_{\text {corr }}\right)$ is respectively $-150,-334$ and $-752 \mathrm{mV}$, corrosion current $\left(I_{\text {corr }}\right)$ is respectively $1.44 \mathrm{E}-5,1.95 \mathrm{E}-4$ and $7.73 \mathrm{E}-3 \mathrm{~A}$. The solid-liquid interface information at pyrite surface achieved by EIS measurements reveals an important reason of the difference between the values of $E_{\text {corr }}$ and $I_{\text {corr }}$ in the three studied fluids. The electrochemical studies in this work also provide a promising method for research into the corrosion of other conductive sulfide minerals in high pressure hydrothermal fluids.
\end{abstract}

Keywords: Pyrite; high pressure hydrothermal fluids; Tafel; electrochemical impedance spectroscopy

\section{FULL TEXT}

(C) 2017 The Authors. Published by ESG (www.electrochemsci.org). This article is an open access article distributed under the terms and conditions of the Creative Commons Attribution license (http://creativecommons.org/licenses/by/4.0/). 